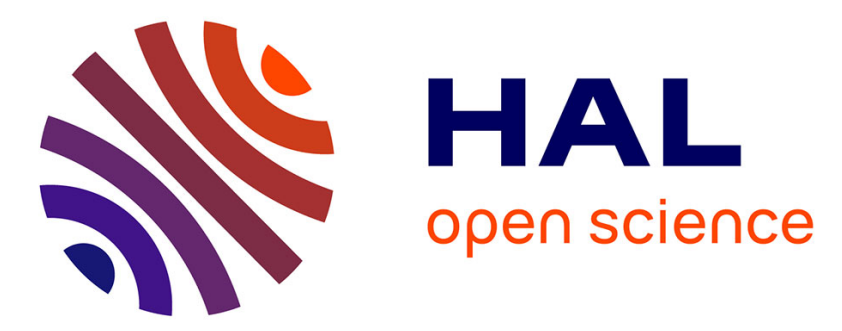

\title{
Morphotectonic evolution of the Jebel Bou Naceur in the South Middle Atlas Fault Zone (Morocco)
}

\author{
Bernard Delcaillau, E. Laville, Jean-Michel Carozza, Olivier Dugué, M.
} Charroud, M. Amrhar

\section{- To cite this version:}

Bernard Delcaillau, E. Laville, Jean-Michel Carozza, Olivier Dugué, M. Charroud, et al.. Morphotectonic evolution of the Jebel Bou Naceur in the South Middle Atlas Fault Zone (Morocco). Comptes Rendus Géoscience, 2007, 339 (8), pp.553-561. 10.1016/j.crte.2007.06.005 halshs-01066245

\section{HAL Id: halshs-01066245 \\ https://shs.hal.science/halshs-01066245}

Submitted on 19 Sep 2014

HAL is a multi-disciplinary open access archive for the deposit and dissemination of scientific research documents, whether they are published or not. The documents may come from teaching and research institutions in France or abroad, or from public or private research centers.
L'archive ouverte pluridisciplinaire HAL, est destinée au dépôt et à la diffusion de documents scientifiques de niveau recherche, publiés ou non, émanant des établissements d'enseignement et de recherche français ou étrangers, des laboratoires publics ou privés. 


\title{
Morphotectonic evolution of the Jebel Bou Naceur in the South Middle Atlas Fault Zone (Morocco)
}

\author{
Bernard Delcaillau $^{\mathrm{a}, *}$, Edgard Laville ${ }^{\mathrm{a}}$, Jean-Michel Carozza ${ }^{\mathrm{b}}$, Olivier Dugué ${ }^{\mathrm{a}}$, \\ Mohamed Charroud ${ }^{\mathrm{c}}$, Mostafa Amrhar ${ }^{\mathrm{d}}$ \\ ${ }^{a}$ UMR-CNRS 6143, M2C « Morphodynamique continentale et côtière », 24, rue des Tilleuls, 14000 Caen, France \\ ${ }^{\mathrm{b}}$ Faculté de géographie, université Louis-Pasteur, 3, rue de l'Argonne, 67083 Strasbourg cedex, France \\ ${ }^{\mathrm{c}}$ Département de géologie, faculté des sciences et techniques, Saiss-Fès, BP 2002, Fès, Morocco \\ ${ }^{\mathrm{d}}$ Faculté des sciences, université Cadi-Ayad, BP 2390, 40000 Marrakech, Morocco
}

Received 25 July 2006; accepted after revision 18 June 2007

Available online 17 August 2007

Presented by Jacques Angelier

\begin{abstract}
In eastern Morocco, fault-related folds develop above the South Middle Atlas fault that separates the J. Bou Naceur 'pop-up' structure and the Missour Basin, filled with alluvial sediments. Using a combination of surfaces, field observations and digital topographic information, we have investigated several geomorphic criteria and geometry of depositional surfaces governed by the relief's growth. The propagation of the deformation is recorded by warped segmented fans that moved southeastward and wellpreserved geomorphological features of tectonic origin. Uplift of the anticline hinges and acceleration of valley incision since the Late Pliocene are considered a consequence of the ongoing NW-SE convergence between Africa and Eurasia. A scenario of morphotectonic evolution of this active mountain front is proposed. To cite this article: B. Delcaillau et al., C. R. Geoscience 339 (2007).
\end{abstract}

(C) 2007 Académie des sciences. Published by Elsevier Masson SAS. All rights reserved.

\section{Résumé}

Évolution morphotectonique du djebel Bou Naceur dans la zone de faille sud-orientale du Moyen Atlas (Maroc). La zone de faille sud-orientale du Moyen Atlas (SMAFZ) apparaît comme un exemple favorable pour tester la sensibilité des marqueurs géomorphologiques de l'évolution récente d'un front montagneux. On a identifié un certain nombre d'indices géomorphologiques et sédimentaires de l'évolution récente de la zone de failles et des rides anticlinales frontales développées au pied du djebel Bou Naceur (Moyen Atlas, Maroc). La propagation de la déformation quaternaire est enregistrée par les anomalies de drainage, la géométrie actuelle des surfaces des dépôts pléistocènes (cônes alluviaux et terrasses fluviatiles) et les ruptures de profils en long des oueds recoupant les plis. Cette étude, réalisée dans les vallées du Chegg-el-Arg et du Beni Ouriach, montre clairement que la croissance des anticlinaux est étroitement contrôlée par le passage d'une rampe latérale dextre (faille de Chegg El Ard) à une zone de chevauchement frontal. L'accélération de l'incision fluviale depuis la fin du Pliocène traduit le maintien d'une activité tectonique pouvant être liée au ralentissement des processus de subduction en Méditerranée occidentale, permettant une

\footnotetext{
* Corresponding author.

E-mail address: bernard.delcaillau@unicaen.fr (B. Delcaillau).
} 
diffusion de la déformation éloignée des limites de celle-ci. Pour citer cet article : B. Delcaillau et al., C. R. Geoscience 339 (2007).

(C) 2007 Académie des sciences. Published by Elsevier Masson SAS. All rights reserved.

Keywords: Neotectonics; Geomorphology; Fluvial pattern; Alluvial fans; Middle Atlas; Morocco

Mots clés : Néotectonique ; Géomorphologie ; Réseau de drainage ; Cônes alluviaux ; Moyen Atlas ; Maroc

\section{Version française abrégée}

C'est dans la zone frontale des chaînes de montagnes que les marqueurs géomorphologiques de la tectonique récente sont mieux exprimés [2,7,8,14,20,22]. La croissance des anticlinaux combine le jeu des chevauchements, la propagation latérale de la déformation et l'érosion fluviale. L'objectif de cette note est de montrer comment le front chevauchant méridional du Moyen Atlas contrôle étroitement la propagation radiale des rides anticlinales et le développement de cônes alluviaux coalescents sur la bordure nord-ouest du bassin sédimentaire de Missour. La zone de faille Sud Moyen-Atlasique (South Middle Atlas Fault Zone ou SMAFZ) constitue un front montagneux majeur culminant au djebel Bou Naceur (3326 m). Le djebel Bou Naceur est un exemple de pop-up taillé dans les formations marno-calcaires jurassiques. Le mouvement chevauchant de ce front montagneux aurait débuté au Miocène [5,17]. De récents travaux d'ordre géologique montrent de nombreuses évidences de l'activité tectonique quaternaire $[10,13,19]$.

Le croisement de nouvelles données géomorphologiques, sédimentologiques et structurales nous permet d'évaluer l'évolution récente d'un front montagneux et de déterminer la chronologie des plis de rampe déformant des séries détritiques plio-quaternaires. Pour étudier l'évolution morphotectonique du front, on utilise des images Landsat TM, un modèle numérique de terrain et les données de terrain. Les critères les plus pertinents sont l'organisation du drainage actuel et passé, la géométrie actuelle des cônes de différentes générations et les profils en long des cours d'eau et des paléo-talwegs. C'est dans les vallées du Bou Nasseur et de Chegg el Ard que ces méthodes géomorphologiques sont appliquées sur le système de plis frontaux qui déforment à la fois les formations conglomératiques pliocènes (formation du Bou Irhardaene ou BI) et les dépôts de cônes pléistocènes.

Le réseau de drainage développé sur le front du SMAFZ enregistre une activité néotectonique déjà reconnue $[12,16]$. Dans cette zone, l'oued du Beni Ouriach (BO) et ses affluents incisent vigoureusement le versant sud du djebel Bou Naceur, tandis que son bassin versant s'accroît radialement, au détriment des bassins adjacents (Fig. 2A). La croissance de son réseau hydrographique s'exerçant au détriment des bassins de Taouchguelt (Tg) et du Taller Touzalt (Tz) s'accompagne de captures fluviales (Fig. 2F). La forte dissection de ces bassins versants montre que la surrection du djebel Bou Naceur est entretenue. Vers le sud-est, le profil en long de l'oued Chegg el Ard est faiblement concave et présente de nombreuses ruptures (knickzones) (Fig. 3D). La basse vallée de cet oued montre quatre ruptures, étroitement liées au jeu de failles inverses aveugles, associées à des plis de propagation. L'étude de son profil en long et la position de ces ruptures démontrent que les plis-failles ont joué simultanément au Quaternaire.

Sur la bordure nord-ouest du bassin sédimentaire de Missour, des plis anticlinaux déforment à la fois les formations détritiques pliocènes (formation de Bou Irhardaene) et les surfaces de cônes pléistocènes qui scellent le SMAF (Fig. 1). À l'exutoire de l'oued Chegg el Ard, quatre surfaces de cônes sont étagées (Fig. 3). L'apex du cône Qf1 se raccorde à l'escarpement bordier et scelle le SMFA. La déformation des cônes Qf1, Qf2 et Qf3 traduit la croissance des anticlinaux orientés $\sim$ N040 et faiblement déversés vers le sud-est. Un schéma d'évolution morphotectonique du front $\mathrm{du}$ djebel Bou Naceur est proposé (Fig. 4).

\section{Introduction}

The Late Neogene deformation of active foreland basins and intermontane basins is dominated by thrusting and fault-related folding $[3,10,16]$. Novel studies of tectonic geomorphology have focused folding and deformation/erosion balance in tectonically active mountain belts $[2,7,8,14,20,22]$. Geomorphic systems are analysed with intent to detect the various responses of landforms and drainage pattern to Late Quaternary deformation $[7,14,20]$. The relationship between fault geometry, kinematics of the deformation and geomorphology (topography reliefs, drainage basins, and fan deposit surfaces) allows us to propose growth models of thrust faults in mountain belts $[1,15,21]$.

This paper focused primarily on the interplay between the growing thrust-related fold belt deforming 
(A)

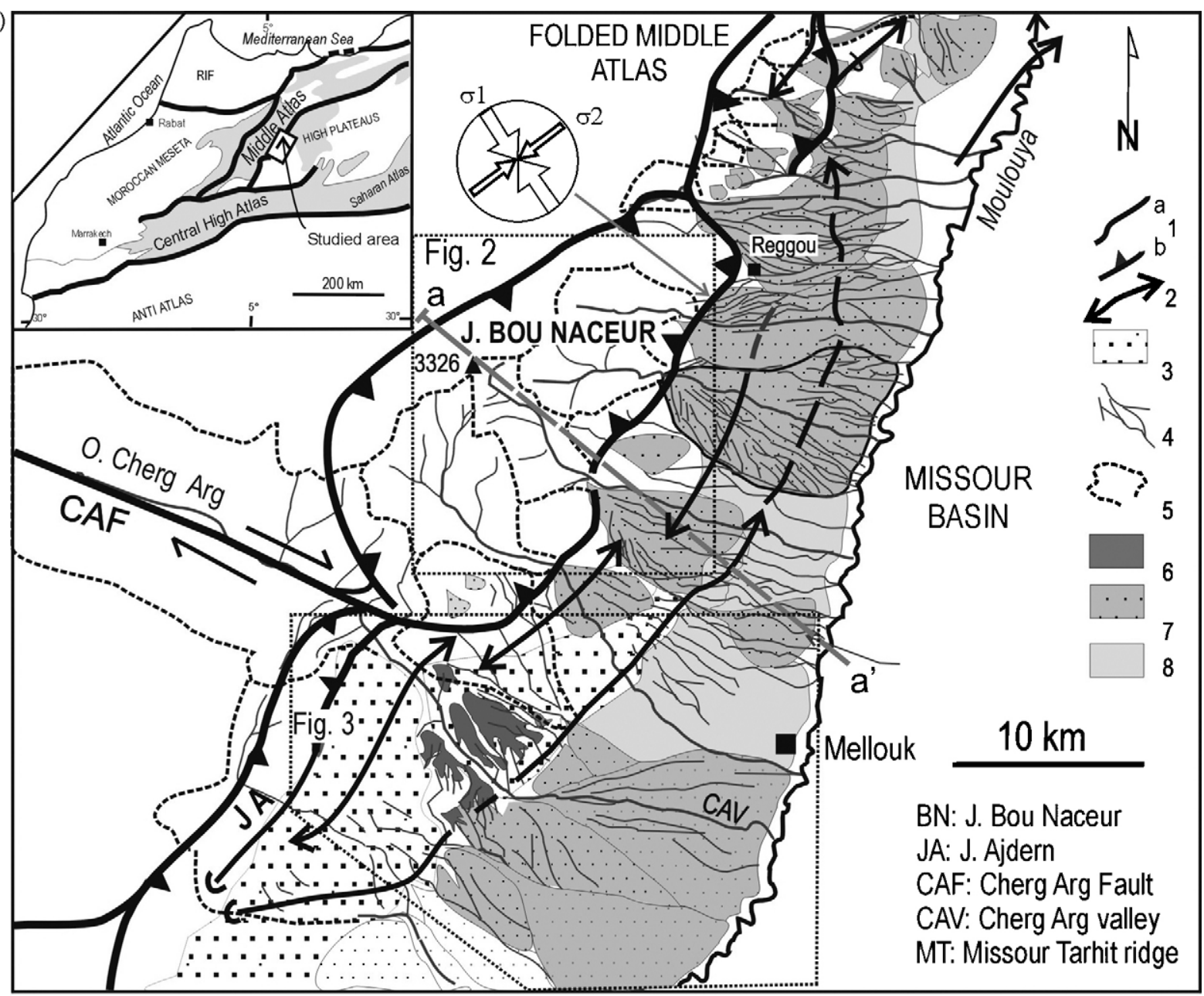

(B) $\quad \mathrm{NW}$

J. Bou Naceur

SE
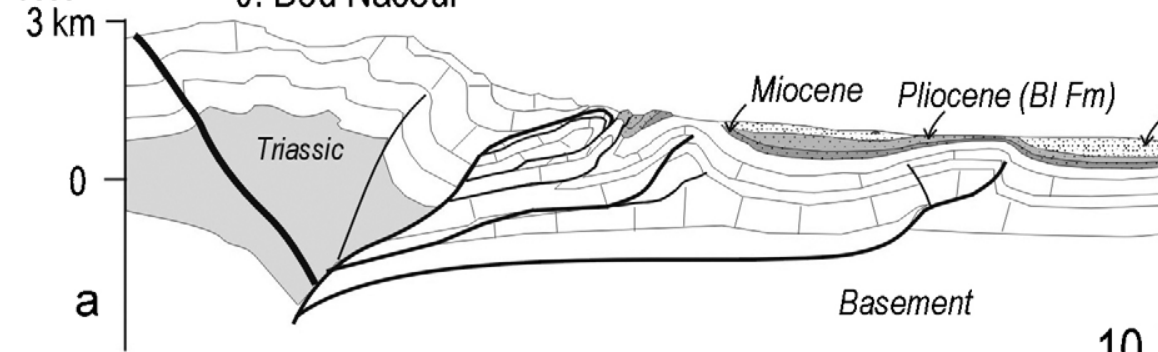
$10 \mathrm{~km}$

Fig. 1. (A) Simplified geological map of the central part of the South Middle Atlas fault zone and of the the Missour Basin. 1a: Fault; 1b: thrust-fault; 2: fold axis; 3: Bou Irhardaene Unit (Pliocene); 4: oueds; 5: drainage divide; 6: Pleistocene alluvial fans; 7: active alluvial fans; 8: fluvial terrace of the Moulouya. (B) a-a': Cross-section through the SMAFZ (modified from Laville et al. [18]).

Fig. 1. (A) Cadre structural du front sud du djebel Bou Naceur et du bassin de Missour. 1a: Faille; $\mathbf{1 b}:$ chevauchement ; $\mathbf{2}$ : axe anticlinal ; $\mathbf{3}$ : unité de Bou Irhardaene $(\mathrm{BI}) ; \mathbf{4}$ : oueds $; \mathbf{5}:$ ligne de partage des eaux des bassins versants ; $\mathbf{6}:$ cônes alluviaux pléistocènes ; $7:$ cônes alluviaux actifs ; $\mathbf{8}$ : terrasse fluviatile de la Moulouya. (B) a-a' $\mathbf{a}^{\prime}$ Coupe géologique transversale de la zone de faille sud-est du Moyen Atlas (d'après Laville et al. [18], modifié). 
(A)

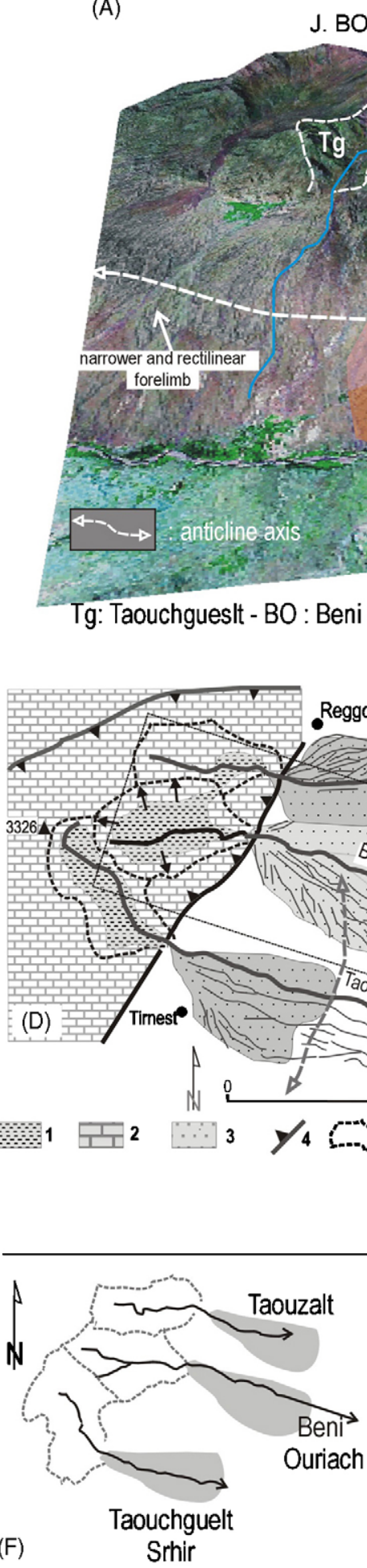

Stade 1
J. BOU NACEUR

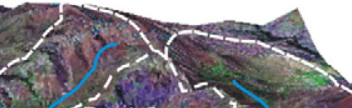
- 'Beni Ouriach"

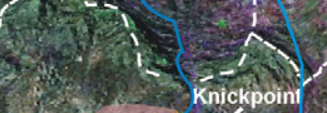

S Strong

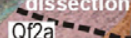
Q $\rightarrow$ Qf2C Lower dissection
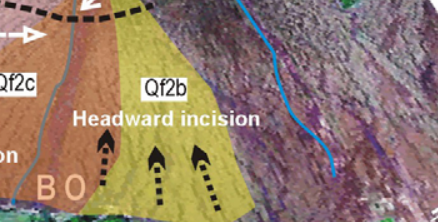

(B)

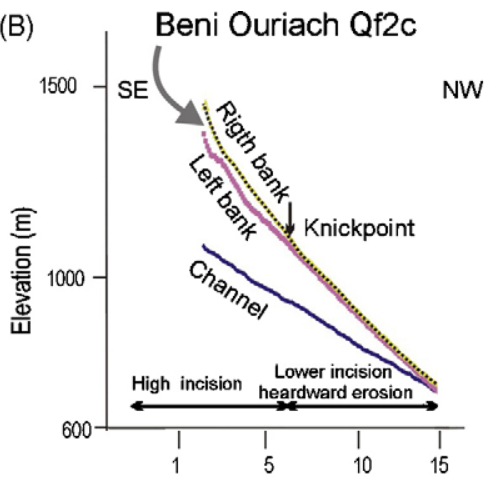

NW

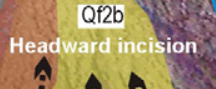
A : (x) 2. $8-x \rightarrow 40$
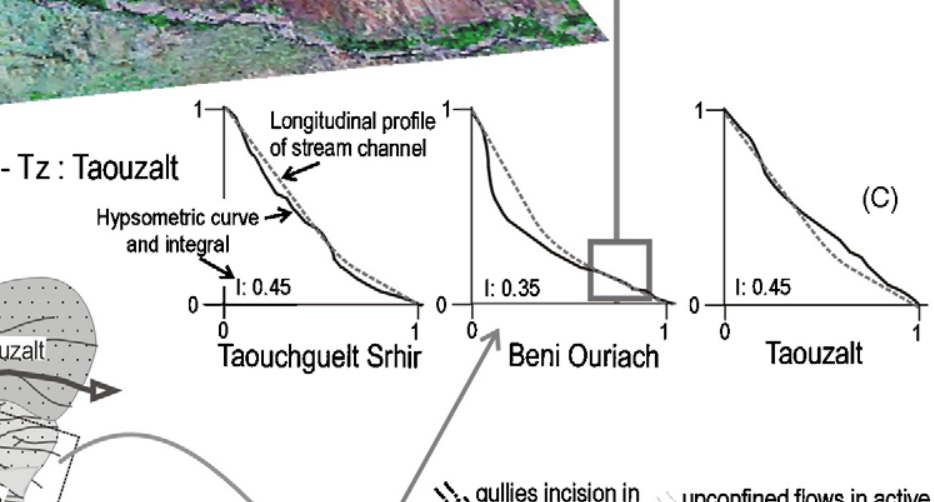

uriach

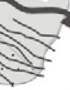

guelt Srhir

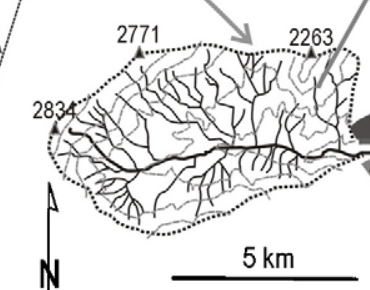

gullies incision in unconfined flows in active fan lobes unconfined fiows in (1)

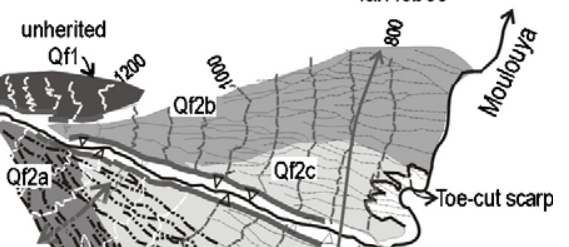
$10 \mathrm{kM}$

$\square$ Qf2d $\square$ Qf2c $\square$ oldest $2 b$

\section{Qf2a}

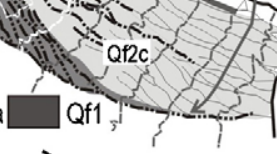

(E)

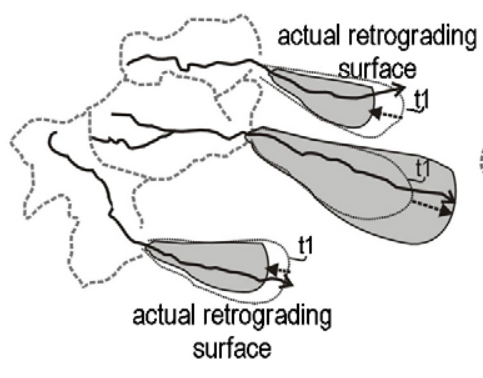

stade 2 (actual)

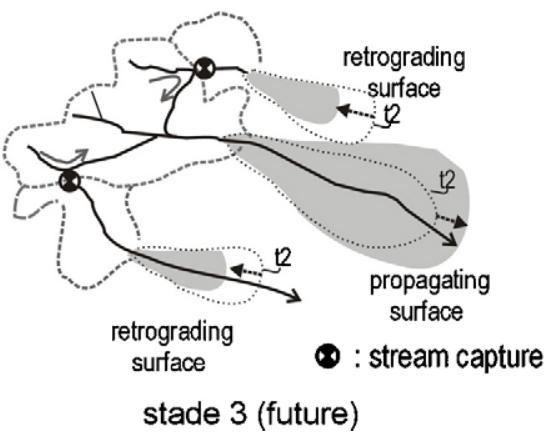


Quaternary alluvial fan surfaces and drainage patterns on the southern flank of the Folded Middle Atlas (Morocco) (Fig. 1). The purpose is to use geomorphological, structural, and sedimentological data to constrain the geometry, kinematics, and timing of Quaternary deformation. The Chegg el Ard and the Beni Ouriach Valleys cross the Bou Naceur perpendicularly to the main structure trend. The growing folds emerge amid a broad, sloping piedmont mantled by alluvial fans. Our aim is to show that the related process of fold growth and drainage evolution in these valleys can be observed acting together, their interactions being clearly expressed in the geological and morphological records (Fig. 2). They are shown by: (i) perennial and ephemeral streams that respond by incising across the fold axis; (ii) the relative age of deformed alluvial fan surface that indicates continued folding through the Quaternary; (iii) the set of uplifted terraces flanking dry valleys and antecedent rivers that are controlled by the propagation of the deformation.

\section{Geological setting}

The Atlasic system constitutes the most prominent morphotectonic features of North Africa [11,13]. Active tectonics in the Moroccan High Atlas has been recently evaluated $[10,19,20]$. The southeast boundary of the Folded Middle Atlas corresponds to the SMAFZ, where Jurassic carbonates are thrust onto coarse deposits of the Neogene Missour Basin [15]. The beginning of SMAFZ thrusting dates back to Miocene times [5,17]. The Missour Basin is an intramontane depression separating the High from the Middle Atlas. This basin is bounded by thrust faults that have a right-lateral component slip on the southern border of the High Atlas and by faults that have a left-lateral component slip to the southwestern part of the folded Middle Atlas, which result in an escape of the basin toward the northeast $[3,17]$. Thrusts and folds of the southern margin of the Middle Atlas affect the Plio-Quaternary deposits that are stacked vertically in the northwestern border of the basin (Fig. 1). The set of structures observed suggests that reverse and thrust faulting along the central part of the SMAFZ are combined with left-lateral slip along north-south striking faults of its southwest termination and right-lateral faulting along east-northeast striking faults of the east-northeast termination [16]. Quaternary activity has been previously discussed by Gomez et al. [12]. However, no significant information has been published on the recent morphotectonic evolution of this range front to establish whether the modern geomorphological features represent a rapid response to tectonic motion and uplift resulting from the NW-SE convergence of Africa and Europe.

\section{Methods}

The purpose of this paper is to use (1) geomorphological and structural data to describe the evolution of drainage pattern and discuss its neotectonic meaning, and (2) the timing of deformation. Geomorphic markers (drainage pattern development, fault scarps, and uplifted Quaternary alluvial fans) have been used to evaluate the uplift and along the active thrust system. Landsat satellite image data, geological maps, Digital Elevation Models (DEM) that result from Shuttle Radar Topographic Missions (SRTM) and field observations are combined to underline the propagation of the faultrelated folds. The topographic parameters, including drainage asymmetry, stream and palaeotalweg long profiles and distribution of alluvial fan surfaces, are extracted from a DEM. The present geometry of uplifted terraces allows us to indicate the timing of deposition and uplift of a frontal fold-thrust system. Indices have been used to identify recent uplifts. Alluvial fans (Qf1 through Qf4) are mapped based on stratigraphy and surficial morphology. The studied anticlinal ridges are compared with different faultrelated folds in order to outline the relation between folding processes and erosion.

Fig. 2. Geomorphic setting of the southern front of the Bou Naceur. (A) Block-diagram of the J. Bou Naceur, resulting from the superposition of the image from Shuttle Radar Topographic Missions (SRTM) and the topographic elevation model. (B) Longitudinal profiles of the Beni Ouriach and its alluvial fan (Qf2c). (C) Normalized longitudinal profiles and hypsometric curves and integrals of the Taouchguelt Srhir, Beni Ouriach, and Taouzalt rivers. (D) Simplified geological map of watersheds and distribution of alluvial fans (bajada). 1: Toarcian marls; 2: Jurassic calcareous; 3: alluvial fans; 4: thrust fault; 5: drainage divide; 6: radial headward fluvial erosion. (E) Alluvial fan system of the Beni Ouriach from the oldest (Qf1) to the youngest ( (Qf2c). (F) Evolution of the Beni Ouriach drainage basin produced by headward dissection and stream captures.

Fig. 2. Cadre géomorphologique du front du Bou Naceur. (A) Superposition d'une image radar (SRTM) et d'un modèle numérique de terrain du djebel Bou Naceur. (B) Profils en long de l'oued Beni Ouriach et son cône alluvial (Qf2c). (C) Profils en long normalisés et courbes intégrales hypsométriques des cours d'eau de Taouchguelt Srhir, Beni Ouriach et Taouzalt. (D) Schéma géologique simplifié des bassins versants et distribution des cônes alluviaux coalescents. $\mathbf{1}:$ marnes toarciennes $; \mathbf{2}$ : calcaires jurassiques ; $\mathbf{3}:$ cônes alluviaux $; \mathbf{4}:$ chevauchement $; \mathbf{5}:$ ligne de partage des eaux ; 6 : érosion régressive radiale. (E) Générations de cônes alluviaux associés à l'oued Beni Ouriach (Qf2c). (F) Évolution du bassin versant du Beni Ouriach par érosion régressive et par captures fluviales. 


\section{Recent evolution of the J. Bou Naceur pop-up structure based on geomorphic indices}

The SMAFZ constitutes a topographic feature that culminates at Bou Naceur (3326 m) [6,12] (Fig. 1A). This fault-scarp runs along an $\mathrm{N} 40^{\circ} \mathrm{E}$ direction. The Bou Nasser ridge, which continues for about $25 \mathrm{~km}$, shows a strong topographic relief $(2500 \mathrm{~m})$. The steepened southeastern flank of the Middle Atlas outlines relief energy in the left side of the Moulouya and lower energy in the right side. Long straight southeastern facing topographic scarp gives evidence of an active fault zone [12]. This thrust front continued to be active during the Pliocene, when Cretaceous and the overlying Bou Irhardaiene Fm. (BI Fm) [4] coarse deposits were faulted and folded by the J. Bou Naceur thrust system [16]. Synclines are infilled by PlioPleistocene sequences of the Missour Basin, while anticlines merge, exhibiting locally Jurassic and Cretaceous rocks. The folding affecting the Pliocene conglomerates and Pleistocene sediments is represented by gentle and southeast-vergent anticlines, which trend to N40 narrow anticlines that gently deform the conglomerates of the BI Fm.

In the lower Chegg el Arg River, detailed structural analyses show that there was a succession of laterally relayed thrusts (Fig. 1A). These faults patterns outline the J. Bou Naceur 'pop-up' structure. Several asymmetric fault-propagation folds are identified in the eastern part of the frontal fault zone (Fig. 1B). Blind structures presumably exist beneath the Missour plain ahead of frontal thrust. These folds, which develop above north-dipping reverse faults, separate the pop-up structure from the Missour Basin filled with alluvial sediments. The fans slope toward the valley floor and coalesce to form a continuous alluvial apron around much of the valleys (Fig. 1). The valley is active and represents a water gap related to an ongoing drainage network antecedent to the folding.

\subsection{Bedrock incision driven by uplift: example of the Beni Ouriach drainage pattern}

The Beni Ouriach drainage basin is dominated by a high-stream frequency, in contrast with the adjacent Taouchguelt ( $\mathrm{Tg}$ ) and Taouzalt (Tz) watersheds that are characterized by low-stream frequency (Fig. 2A and D). The strong asymmetry of these two watersheds results from high headward dissection of the Beni Ouriach drainage basin. The Taouchguelt and Taller Touzalt Rivers are characterized by sub-rectilinear profiles and hypsometric curves (Fig. 2C). However, the Beni
Ouriach River shows a profile and a hypsometric curved concave form that result from the strong bedrock incision of the Toarcian marls (Fig. 2B). Therefore, the bedrock incision can be strongly driven by the uplift of the Bou Naceur block produced by the thrusting activity. The alluvial fan (BO) is still cut by the Beni Ouriach River and the recent fan surfaces register a knickpoint (Fig. 2B). This clear slope break, more underlined on the right bank of the Beni Ouriach fan than on its left bank, could result in the northeastward lateral propagation of the asymmetric anticline (Fig. 2A). This fold is characterized by a narrow and rectilinear forelimb.

\subsection{Deformation of Quaternary segmented alluvial fans}

The development of the southeastern flank of the $\mathrm{J}$. Bou Naceur is recorded by uplifted imbricate fans that moved southeastward and the coarse detrital system, which are incised and recycled forward in large recent alluvial fans. The core of these anticlines is made up of bedded, Pliocene conglomerates (Bou Irhardaiene Fm.) that are unconformably overlain by Quaternary terraces and alluvial deposits. Streams are well confined and channelized at the fan heads. Southwestward, these fans are free to expand, whereas the fan expansion is constrained to the northeast by the narrowness of the Moulouya Valley. The saturation factor $S$ is defined by: $S=x / w$ ( $S$ : saturation factor, $w$ : half-spacing of the outlets, $x$ : length or progradation distance) [9]. The oversaturation $(S>1)$ of the southwestern part of the Missour Basin indicates the building of fans that migrate basinward as coalesced alluvial fan surface or bajada. Fans on the $\sim 12 \mathrm{~km}$-wide bajada grade down to southeast-trending wide axial stream channels (Fig. 1A).

The Beni Ouriach alluvial fan (BO) has a steep gradient from $9^{\circ}$ in the fan head to $2-3^{\circ}$ in its distal part (Fig. 2A). The fan system consists of several surfaces of different heights. The highest surface is referred to as Qf1. The Beni Ouriach outlet shows four Late Quaternary segmented fans (Qf2a, Qf2b, and Qf2c) (Fig. 2E). The distal part of the Qf2c is subjected to an active toe cutting faster than lateral avulsion. The present Beni Ouriach channel is an active large thalweg ( 300-400 $\mathrm{m}$ ) perched between 25 to $30 \mathrm{~m}$ above the terrace of the Moulouya. The stream cuts deeply the fan deposits and the entrenchment of the Beni Ouriach fan system is the result of uplifting.

To the southwest, the Chegg el Ard Valley is characterized by segmented fan profiles and by incised 
fan-head that are largely exposed on the SMASZ scarp (Fig. 3A). A hanging-wall anticline deforms Pleistocene sedimentary cover deposits (Fig. 3A and C). The alluvial fan system is composed of four stepped surfaces, from the youngest (Qf4) to the oldest (Qf1). The apices of topographically higher inactive fan surfaces Qf1 and Qf2 overlap the thrust front. The uplift of anticlines is characterized by an incision of these warped fan surfaces: $250 \mathrm{~m}$ above the Chegg el Ard for abandoned Qf1, $200 \mathrm{~m}$ for Qf2, and $120 \mathrm{~m}$ for Qf3. The fan system is characterized by five entrenchments: the oldest segmented fans are located in the middle part of the valley, while the youngest are situated close to the Moulouya River in the Southeast. Deposition of younger fan units over older deposits indicates hinge migration in fault-related anticlines during deposition of the growth strata. In the frontal zone, the incision of the Chegg el Ard decreases to a maximum of $300 \mathrm{~m}$. At the southwestern part of this river, coalesced secondary fans are formed primarily from the erosion and redeposition of older Pleistocene deposits (Fig. 3B). The Late Holocene fans are actively prograding onto the floodplain. Reworking of the proximal parts of successive fan accumulations attests to a subsequent continued tectonic relative uplift of the source area.

The Chegg el Ard stream long profile indicates a concave-up shape (Fig. 3C). The thalweg profile registers a clear knickzone in the bending zone of the CAF (Fig. 3A and C). The analysed Chegg el Ard stream long profile shows several knickpoints (K1 to K4). The
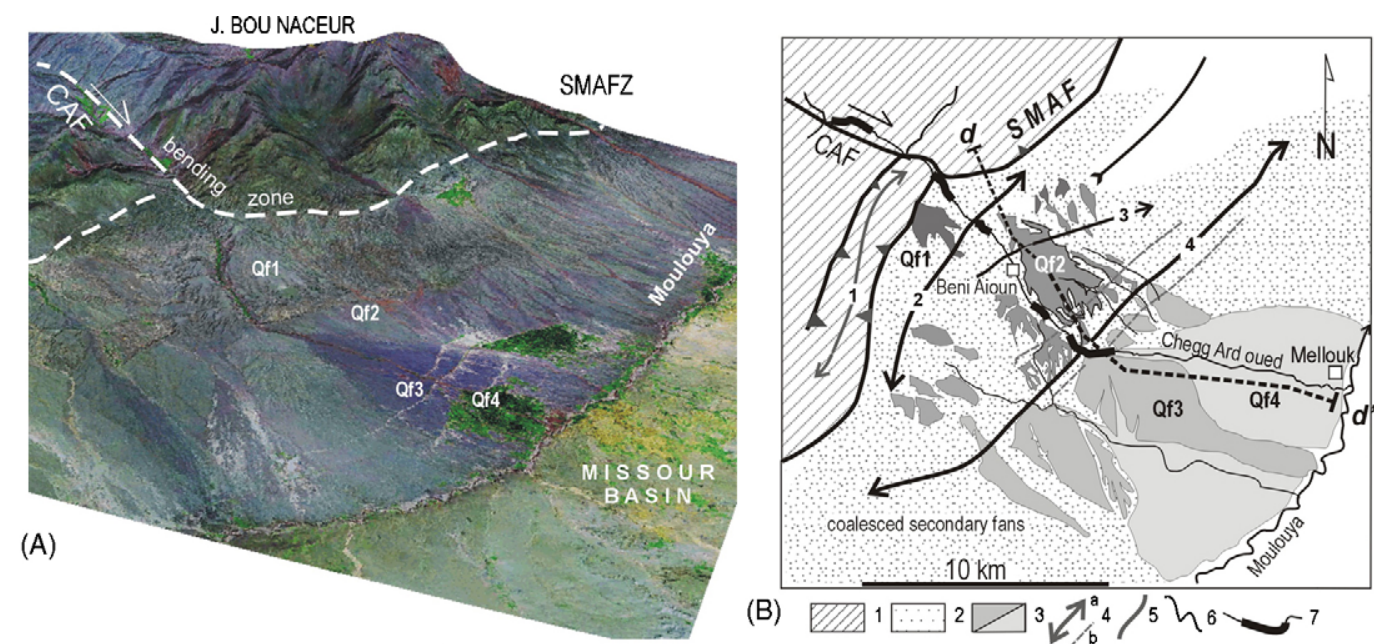

(B)

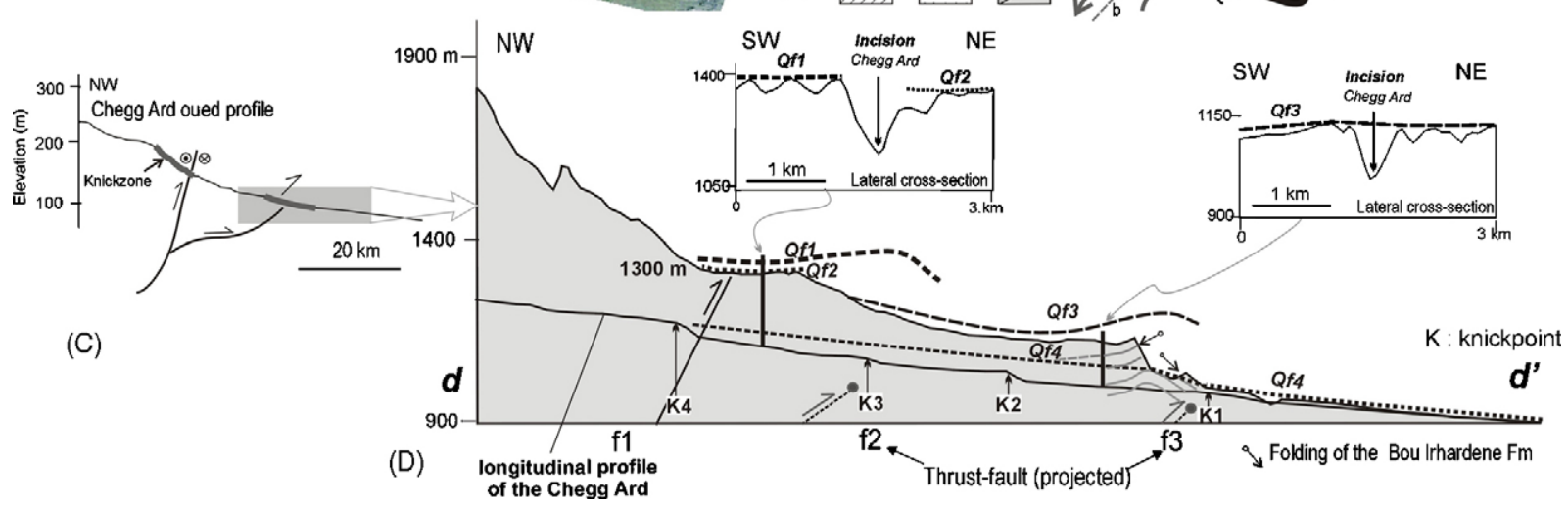

Fig. 3. Morphotectonics of the lower Chegg el Ard Valley. (A) Digital Elevation Models that result from Shuttle Radar Topographic Missions (SRTM) of the Chegg el Ard Valley and the central Missour Basin. (B) The Chegg el Ard alluvial fan system. 1: Jurassic substratum including Liassic carbonate; recent anticlinal axis; 2: Bou Irhardaene Unit; 3: Qf1, 2, 3 etc.: succession of the alluvial fan deposits; 4a: anticline; 4b: monocline; 5: oueds; (6): knickzone. (C) Longitudinal profile of the Chegg el Ard River. (D) Deformed Pleistocene terrace surfaces and transverse profiles, showing Pleistocene alluvial fan surfaces.

Fig. 3. Morphotectonique de la basse vallée du Chegg el Ard. (A) Image Landsat, Thematic Mapper) de la vallée du Chegg el Ard et du bassin intramontagneux de Missour. (B) Système de cônes alluviaux. 1 : Substratum jurassique ; 2 : unité du Bou Irhardaene ; 3 : cônes alluviaux quaternaires ; $\mathbf{4 a}$ : anticlinal ; $\mathbf{4 b}$ : relief de crêt ; 5 : oueds : $\mathbf{6}:$ knickzone. (C) Profil longitudinal du Chegg el Ard. (D) Profils transversaux traduisant la distribution des cônes pléistocènes. 


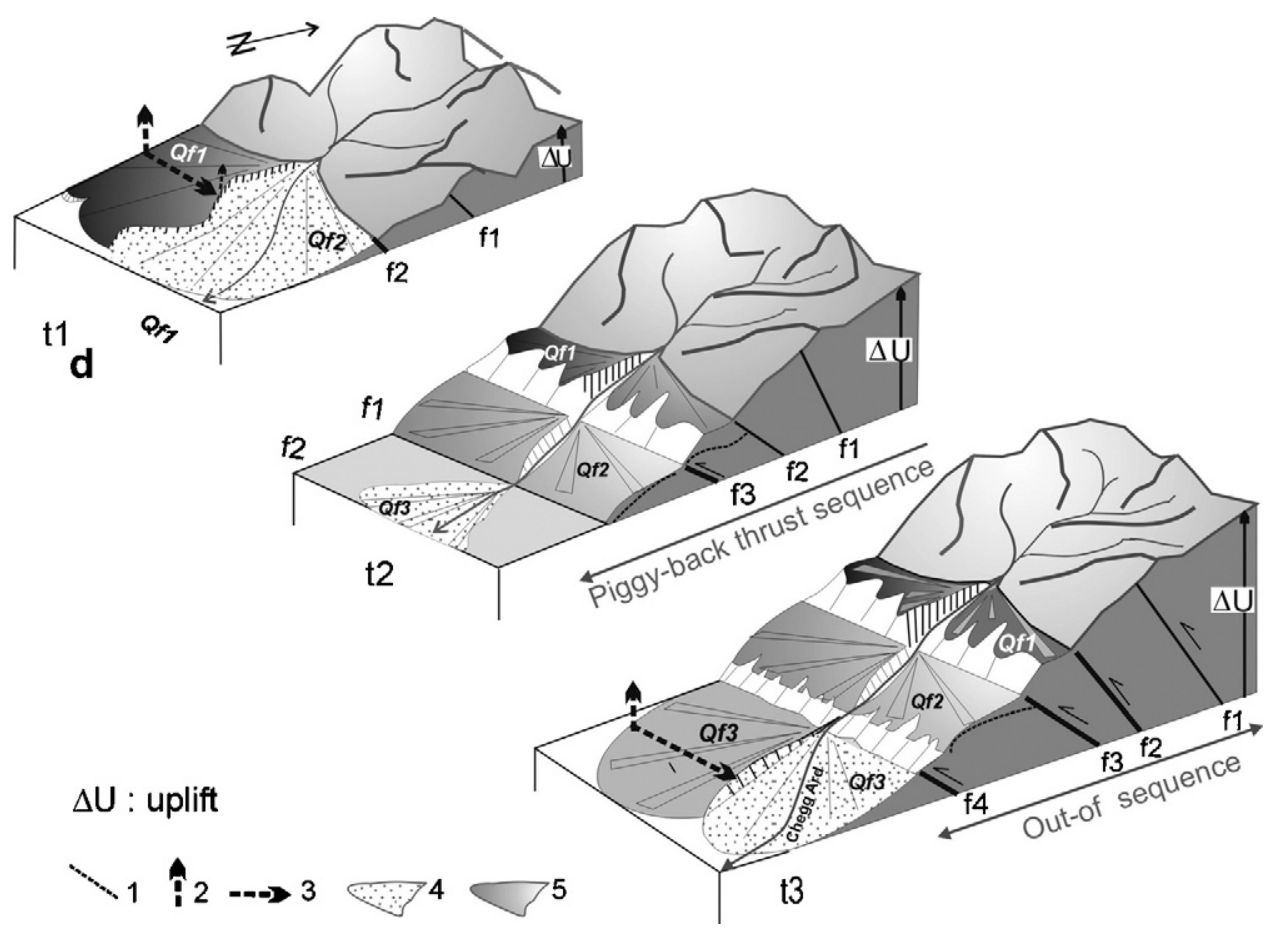

Fig. 4. Sketches showing the emplacement of the different alluvial fans and the propagation of the deformation.

Fig. 4. Schémas montrant l'emplacement des différents cônes alluviaux segmentés et la propagation de la déformation.

narrowing of the valley towards the knickzones and the increase in the channel gradients imply that this valley segments are in a phase of valley lowering and ongoing dissection into the bedrock. This step-like steepening in the channel profile initiated by sudden base-level fall could coincide with active fault-related folds.

A scenario of morphological development of the anticline ridges is proposed (Fig. 4). The steepening of the oldest fans (Qf1, 2, 3), with a concomitant down-fan shift in the depositional area, attests to the uplift tectonic and the growing of fault-related folds. These multistep alluvial fan surfaces indicate the displacement from the northwest to the southeast of these structures, perpendicular to the Middle Atlas belt. Nevertheless, the present position of knickpoints (Fig. 3D) could indicate a present simultaneous activity of blind reverse faults.

\section{Conclusion}

In this paper, Plio-Quaternary deformation along the Middle Atlas front is demonstrated. Topography relief, active tectonics, and drainage pattern are used to provide a unified picture of the Quaternary development of the central segment of the SMAFZ. The timing of the deformation is constrained by geomorphic information recorded in the frontal zone. Using a combination of field observations and digital topographic information, several geomorphic criteria (topographic relief, development of watersheds and drainage networks, geometry of terrace surfaces) show evidence of propagation of folds accommodating convergence of the SMAFZ. The Chegg el Ard and the Beni Ouriach Valleys are active and represent water gaps related to an ongoing drainage network antecedent to the folding. The geomorphic data imply that the synfolding incision is due to the uplift and tectonic deformation, and knickzones in the longitudinal profiles of rivers represent headward shifting erosional front. The position of these knickpoints shows that all the faults are active synchronously. We propose a normal sequence of thrusts of the Jebel Bou Naceur.

\section{References}

[1] R. Ahmadi, J. Ouali, E. Mercier, J.-L. Mansy, B. Van-Vliet Lanoë, P. Launeau, F. Rhekhiss, S. Rafini, The geomorphologic responses to hinge migration in the fault-related folds in the Southern Tunisian Atlas, J. Struct. Geol. 28 (4) (2006) 721-728.

[2] D.W. Burbank, R.S. Anderson, Tectonic Geomorphology, Blackwell Science, 2001.

[3] W. Beauchamp, M. Barazangi, A. Demnati, M. El Alji, Intracontinental Rifting and Inversion: the Missour Basin and Atlas Mountains, Morocco, AAPG Bull. 80 (9) (1996) 1459-1482. 
[4] M. Bernini, M. Boccatelli, J. El Mokhtari, R. Gelati, S. Iccarino, G. Moratti, G. Panini, Données stratigraphiques nouvelles sur le Miocène supérieur du bassin de Taza-Guercif (Maroc nordoriental), Bull. Soc. geol. France 366 (1992) 159-163.

[5] B. Coletta, Évolution néotectonique de la partie méridionale du bassin de Guercif (Maroc oriental), thèse de $3^{\mathrm{e}}$ cycle, University of Grenoble, France, 1977.

[6] G. Colo, Contribution à l'étude du Jurassique du Moyen Atlas septentrional, Note. Mem. Serv. Geol. Maroc 139bis (1964) $1-226$.

[7] B. Delcaillau, Reliefs et Tectonique récente, Vuibert, Paris, 2004.

[8] R.J. Dorsey, J.J. Roering, Quaternary landscape evolution in the San Jacinto fault zone, Peninsular Ranges of Southern California: Transient response to strike-slip fault initiation, Geomorphology 73 (2006) 16-32.

[9] G.S. Fraser, P.G. DeCelles, Geomorphic controls on sedimentary accumulation at margins of foreland basins, Basin Res. 4 (1992) 233-252.

[10] D. Frizon de Lamotte, A. Michard, O. Saddiqi, Quelques développements récents sur la géodynamique du Maghreb, C. R. Geoscience 38 (2006) 1-10.

[11] D. Frizon de Lamotte, B. Saint Bézar, R. Bracène, E. Mercier, The two main steps of the Atlas building and geodynamics of the western Mediterranean, Tectonics 19 (4) (2006) 740-761.

[12] M. Garcia, G. Hérail, Fault-related folding, drainage network evolution and valley incision during the Neogene in the Andean Precordillera of Northern Chile, Geomorphology 65 (2005) 279-300.

[13] F. Gomez, W. Beauchamp, M. Barazangi, Role of the Atlas mountains (Northwest Africa) within the African-Eurasian plate-boundary zone, Geology 28 (2000) 775-778.
[14] E.A. Keller, L. Gurrola, T.E. Tierney, Geomorphic criteria to determine direction of lateral propagation of reverse faulting and folding, Geology 27 (6) (1999) 515-518.

[15] K.Y. Lai, Y.G. Chen, J.H. Hung, J. Suppe, L.F. Yue, Y.W. Chen, Surface deformation related to kink-folding above an active fault: evidence from geomorphic features and co-seismic slips, Quat. Int. 147 (1) (2006) 44-54.

[16] E. Laville, B. Delcaillau, M. Charroud, O. Dugué, A. Brahim, G. Cattaneo, P. Deluca, A. Bouazza, The Plio-Pleistocene evolution of the Southern Middle Atlas Fault Zone (SMAFZ) front of Morocco, Int. J. Earth Sci. 96 (3) (2007) 497-515.

[17] J. Martin, Le Moyen Atlas central, Étude géomorphologique, Notes Mem. Serv. Geol. Maroc 228-228bis (1973) (445 p., 5 cartes : 1/100 000).

[18] J.-L. Morel, E.M. Zouine, A. Poisson, Relations entre la subsidence des bassins moulouyens et la création des reliefs atlasiques (Maroc) : un exemple d'inversion tectonique depuis le Néogène, Bull. Soc. geol. France 164 (1) (1993) 79-91.

[19] M. Sébrier, L. Siame, E.M. Zouine, T. Winter, Y. Missenard, P. Leturmy, Active tectonics in the Moroccan High Atlas, C. R. Geoscience 338 (1-2) (2006) 65-79.

[20] S.A. Schumm, J.-F. Dumont, J.M. Holbrook, Active tectonics and alluvial rivers, Cambridge University Press, Cambridge, UK, 2000.

[21] S.G. Wells, T.F. Bullard, C.M. Menges, P.G. Drake, P.A. Karas, K.L. Kelson, J.B. Ritter, J.R. Wesling, Regional variations in tectonic geomorphology along a segmented convergent plate boundary, Pacific coast of Costa Rica, Geomorphology 1 (3) (1988) 239-265.

[22] K.X. Whipple, Bedrock rivers and the geomorphology of active orogens, Annu. Rev. Earth Planet. Sci. 32 (2004) 151-185. 